\title{
НЕЙРОГОНИОМЕТРИЯ В УСЛОВИЯХ МИКРОГРАВИТАЦИИ/НЕВЕСОМОСТИ - НОВАЯ ИДЕОЛОГИЯ ПРИБОРОСТРОЕНИЯ ДЛЯ НЕЙРОФИЗИОЛОГИЧЕСКИХ И НЕЙРОМОРФОЛОГИЧЕСКИХ ИЗМЕРЕНИЙ В ПРЕДЕЛАХ ПРОГРАММЫ «БИОН»
}

\section{Градов О.В.}

\section{Институт Энергетических Проблем Химической Физики}

им. В.Л. Тальрозе РАH, o.v.gradov@gmail.com

В космической биологии и медицине хорошо известен эффект воздействия невесомости / микрогравитации на характеристики переноса заряда через мембрану нейрона [1]. У нейрона в данном состоянии в ряде случаев нарушаются процессы формообразования или ориентация отростков из-за отсутствия комплекса нативных сил, действующих на нейроны в гистогенезе (так как нарушены ориентация в поле сил тяготения, нормальная диффузия, биореология). В коллекциях микропрепаратов бывшего Института мозга (Лаборатория нейронной структуры мозга) автором были обнаружены и изучены подобные препараты. По частным сообщениям, ссылающимся на морфометрические работы [2-4], выполненные на материале с биоспутника «Космос-1667» («Бион-7»), при длительном полете наблюдается частичная/фрагментарная инволюция отростков и шипиков, сопровождающаяся приближением формы сомы нейрона к псевдосферической. С точки зрения функциональной морфологии и морфофизиологического тренда в многофакторном анализе данных in situ, логично создание аппаратуры для контроля одновременно электробиофизического/электрофизиологического и нейроморфологического состояния нейронной структуры мозга, культуры нервной ткани ил переживающих слайсов непосредственно в условиях микрогравитации/невесомости в ходе полета. Ранее нами была разработана система пятиосная роботизированная система позиционирования для измерений на переживающих слайсах или в культурах клеток [5], на которой просто демонстрировалась зависимость морфогенеза определенных структур от ориентации в поле тяготения и внешних полях, а также её корреляция с направленной электрофизиологической активностью. Силами привлеченного автором студенческого коллектива был произведен расчет и проектирование культурального бокса и витальной электрофизиологической системы для стереотактического позиционирования, предназначенных для исследования сопряженных изменений в режимах электрофизиологической активности и в морфологических (морфометрических) параметрах нейронных структур (как in vivo или in situ, так и in vitro на слайсах или культуре ткани) при космическом полете (и в контролях — в «нативных» условиях и при центрифугировании).

\section{ЛИТЕРАТУРА}

1. Wallace R. Microgravity and Charge Transfer in the Neuronal Membrane: Implications for Computational Neurobiology // LS\&SM Conf. (Houston), Apr. 3-5, 1995; AIAA-95-1053; NASA-CR-205364.

2. Belichenko P.V. Quantitative analysis of dendritic spines of pyramidal neurons in layerV of the sensomotor cortex of rats exposed on the "Kosmos-1667"biosatellite // Bull. Exp. Biol. and Med., Vol. 105, No 6, pp. 876-878 (1988).

3. Belichenko P.V., Leontovich T.A. Morphometry of giant multipolar neurons of the brain-stem reticular formation of rats carried on board the biosatellite "Kosmos 1667" // Bull. Exp. Biol. and Med., Vol. 107, No 5, pp. $714-717$ (1989). 
4. Belichenko P.V., Krasnov I.B. State of the dendritic spines of pyramidal neurons in layer V of the rat sensomotor cortex after 14-day space flight // Bull. Exp. Biol. and Med., Vol. 112, No. 5, pp. 1659-1660 (1991).

5. Notchenko A.V., Gradov O.V. A Five-Axis Arm-Manipulator Laser System and Algorithm for Digital Processing of Output Data for Recording and Morpho-Topological Identification of Cells and Tissue Structures. Visualization, Image Processing and Computation in Biomedicine, Vol. 2, DOI: 10.1615/ VisualizImageProcComputatBiomed.2013005967 (2013) 